\title{
GMR
}

\section{Genetic diversity of Bacillus sp producers of amylase isolated from the soil}

A.R.E.O. Xavier ${ }^{1,2}$, E.R. Lima ${ }^{1}$, A.M.E. Oliveira ${ }^{3}$, L. Cardoso ${ }^{2}$, J. Santos ${ }^{2}$, C.H.C. Cangussu' ${ }^{2}$ L.N. Leite' ${ }^{2}$ M.C.L. Quirino², I.G.C. Júnior ${ }^{2}$, D.A. Oliveira ${ }^{1}$ and M.A.S. Xavier ${ }^{1,2}$

${ }^{1}$ Laboratório de Bioprospecção e Recursos Genéticos, Centro de Ciências Biológicas e da Saúde, Universidade Estadual de Montes Claros, Centro de Ciências Biológicas e da Saúde, Laboratório de Bioprospecção e Recursos Genéticos, Montes Claros, MG, Brasil

${ }^{2}$ Laboratório de Microbiologia, Centro de Ciências Biológicas e da Saúde, Universidade Estadual de Montes Claros, Montes Claros, MG, Brasil ${ }^{3}$ Instituto de Ciências Agrárias, Universidade Federal de Uberlândia, Uberlândia, MG, Brasil

Corresponding author: A.R.E.O. Xavier

E-mail: ericsson_aerc@yahoo.com.br

Genet. Mol. Res. 16 (3): gmr16039771

Received July 6, 2017

Accepted August 25, 2017

Published September 27, 2017

DOI http://dx.doi.org/10.4238/gmr16039771

Copyright $(2017$ The Authors. This is an open-access article distributed under the terms of the Creative Commons Attribution ShareAlike (CC BY-SA) 4.0 License.

\begin{abstract}
The microorganisms are the best source of extracellular enzymes since they allow an economical technology with low-resource consumption compared to animals and plants. The amylases are among the most important enzymes being the genus Bacillus one of the most investigated due to its ability to produce this enzyme. The objective of this study was to isolate and analyze the genetic diversity among bacteria of the genus Bacillus sp producer of amylase originated from the soil. To
\end{abstract}

Genetics and Molecular Research 16 (3): gmr16039771 
this end, soil samples were collected and submitted to the condition of extreme temperature. The serial dilution procedure followed by seeding on solid medium containing starch was used for isolation of strains that produce amylase. The microorganisms isolated were subjected to standard morphological methods for presumptive identification of the genus Bacillus. The PCR assay with the universal genetic marker 16S rDNA was used for confirmation of bacterial strain. All the 10 isolates presumptively identified as bacteria amplified a fragment of $370 \mathrm{bp}$ corresponding to the $16 \mathrm{~S} r D N A$ gene. The enzymatic activity was expressed as an enzymatic index (EI), after $24 \mathrm{~h}$ of incubation. All isolate producers of amylase exhibited $\mathrm{EI} \geq 2.0$. The determination of the genetic profile and the clonal relationship among the isolates were performed by the method of ERIC-PCR polymorphism. The isolates of Bacillus spp were divided into 2 groups (I and II). Through this method, the discriminatory capacity of this analysis of polymorphisms was verified in differing producer strains from those not producing amylase.

Key words: Genetic diversity; $16 \mathrm{~S}$ rDNA gene; ERIC-PCR; Bioprospection; Bacillus spp; Amylase

\section{INTRODUCTION}

Because of the ability to withstand extreme physical conditions, microorganisms of the genus Bacillus are considered bio-factories with excellent capacity of production of hydrolytic enzymes. Approximately 50 to $60 \%$ of the global market for enzymes correspond to those produced by bacteria of the genus Bacillus (Schallmey et al., 2004; Kiran et al., 2015; Dash et al., 2015; Ghazala et al., 2016; Ma et al., 2016).

Although several microorganisms are known to produce alkaline proteases and amylases, the strains of Bacillus are preferred due to its exceptional ability to secrete large quantities of highly active enzymes (Oliveira et al., 2007; Wang et al., 2015, 2016; Sánchez Blanco et al., 2016).

The amylases are important industrial enzymes that catalyze the breakdown of glycogen in oligosaccharides from different sizes (Akkaya et al., 2012; Bhange et al., 2016). The amylases are indispensable in the food, textiles, paper, pharmaceutical, and detergent industries (Pandey et al., 2000; Sahnoun et al., 2015; Bhange et al., 2016; Al-Johani et al., 2016). The wide potential application of amylase in industrial and medicinal processes propels an effort on the part of researchers in seeking for the most efficient means of its production (Dash et al., 2015; Gopinath et al., 2017).

The level of production of microbial amylase varies from a microorganism to another, even between the same genus and species. Besides, the level of production of this enzyme also differs depending on the source of the microbe, where isolates of environments rich in starch or amylose produce naturally greater quantities of the enzyme. Factors such as $\mathrm{pH}$, temperature, salt, sources of carbon and nitrogen are vital to the amylase production rate (Liu et al., 2015; Gopinath et al., 2017).

Genotypic methods can be employed to obtain information related to microbial strains that produce enzymes of interest. PCRs based on repetitive elements, among which ERIC and

Genetics and Molecular Research 16 (3): gmr16039771 
BOX and REP-PCR, are among the techniques available that allow the analysis of genetic diversity among isolates of the genus Bacillus (Kumar et al., 2014; García et al., 2015). The objective of this study was to isolate and analyze the genetic diversity among bacteria of the genus Bacillus sp producer of amylase originated from the soil.

\section{MATERIAL AND METHODS}

\section{Isolation of amylolytic bacteria}

Soil samples were collected at the Center for Biological and Health Sciences, State University of Montes Claros, Minas Gerais, Brazil, in June 2017. For the primary screening, a 10 -g sample of surface soil was resuspended in $100 \mathrm{~mL}$ sterile saline solution and subjected to heating at $80^{\circ} \mathrm{C}$ for $15 \mathrm{~min}$. The suspension was mixed and aliquots were transferred to $1-\mathrm{mL}$ tubes containing $9 \mathrm{~mL}$ nutrient broth Biobrás ${ }^{\circledR}$ in procedure of 4 serial dilutions $\left(10^{-2}, 10^{-3}, 10^{-}\right.$ ${ }^{4}$, and $10^{-5}$ ) seeded on medium containing: $10 \mathrm{~g} / \mathrm{L}$ Tryptone, $10 \mathrm{~g} / \mathrm{L}$ starch, $5 \mathrm{~g} / \mathrm{L}$ beef extract and $15 \mathrm{~g} / \mathrm{L}$ Agar-Agar, $\mathrm{pH} 7.4$. The plates were incubated for $24 \mathrm{~h}$ at $37^{\circ} \mathrm{C}$, then stored at $8^{\circ} \mathrm{C}$ for $48 \mathrm{~h}$, and then submitted to the procedure of macroscopic evaluation, count of colonies, and production of amylase. For detection of amylase production, the plates were stained with a solution containing $2 \%$ iodine in $0.2 \%$ potassium iodide for 15 min. The enzymatic determination was expressed by the enzymatic index (EI) using the ratio of the mean diameter of the degradation halo and the mean diameter of the colony (Hankin and Anagnostakis, 1975), following the formula below:

$$
E I=\frac{\text { diameter of the halo }}{\text { diameter of the colony }}
$$

Five amylase producer colonies and 5 non-producers were selected for this study. The isolates that showed higher EI in the culture medium were those that had higher extracellular enzymatic activity.

The morphological characterization was performed by observing the color and appearance of colonies for the presence of brightness or opacity. The colonies were subjected to the standard procedure of Gram staining and visualized in the Nikon Eclipse E2000 optical microscope with $1000 \mathrm{X}$ magnification.

\section{DNA extraction and PCR for detection of the universal bacterial $16 S r D N A$ gene}

Isolated colonies from the plates were subjected to DNA extraction with the kit KAPAExtract ${ }^{\mathbb{B}}$ according to the manufacturer's recommendations. The DNAs were eluted in a final volume of $100 \mu \mathrm{L}$ and subsequently measured by electrophoresis on $1.5 \%$ agarose gel and used in PCR and ERIC-PCRs. The presence of the universal bacterial $16 \mathrm{~S} \mathrm{rDNA}$ gene was verified by PCR with the primers DG74 (5'-AGGAGGTGATCCAACCGCA-3') and RW01 (5'-AACTGGAGGAAGGTGGGGAT-3') generating an amplicon of $370 \mathrm{bp}$ (Greisen et al., 1994). The primers were synthesized by Integrated DNA Technology, USA. The reactions were carried out in a mix containing $2 \mathrm{X} \mathrm{GoTaq}^{\circledR}$ Green Master Mix (Promega Corporation, USA), $\mathrm{MgCl}_{2}(2.5 \mathrm{~mm}), 10 \mu \mathrm{M}$ of each primer, and $50 \mathrm{ng}$ bacterial DNA, in a final total

Genetics and Molecular Research 16 (3): gmr16039771 
reaction volume of $50 \mu \mathrm{L}$. The conditions were as follows: an initial cycle of denaturation at $94^{\circ} \mathrm{C}$ for $5 \mathrm{~min}$ followed by 35 cycles of denaturation at $95^{\circ} \mathrm{C}$ for $30 \mathrm{~s}$, annealing at $57^{\circ} \mathrm{C}$ for 30 $\mathrm{s}$, extension at $72^{\circ} \mathrm{C}$ for $45 \mathrm{~s}$, and a final extension of $10 \mathrm{~min}$. The amplicons were visualized on $1.5 \%$ agarose gel stained with ethidium bromide and photographed and documented. As a positive control of the PCR, a nosocomial strain of Klebsiella pneumoniae previously identified by encoding the universal bacterial $16 S \mathrm{rDNA}$ gene was used.

\section{ERIC-PCR}

The characterization of the genetic profile and the clonal relationship among the isolates of Bacillus spp was performed using analysis of polymorphisms in genomic DNA. For this PCR, preserved primers ERIC-1 (5'-TGTAAGCTCCTGGGGATTAAC-3') and ERIC-2 (5'-AGTAAGTGACTGGGGTGAGCG-3') were used for sequences of the repetitive intergenic consensus of enterobacteria described in the literature (Duan et al., 2009). The reactions were carried out in a mix containing $2 \mathrm{X} \mathrm{GoTaq}^{\circledR}$ Green Master $\mathrm{Mix}, \mathrm{MgCl}_{2}(2.5$ $\mathrm{mm}), 10 \mu \mathrm{M}$ of each primer, and $50 \mathrm{ng}$ bacterial DNA, in a final total reaction volume of $50 \mu \mathrm{L}$. The conditions were as follows: an initial cycle of denaturation at $95^{\circ} \mathrm{C}$ for $5 \mathrm{~min}$ followed by 40 cycles of denaturation at $95^{\circ} \mathrm{C}$ for $30 \mathrm{~s}$, annealing at $57^{\circ} \mathrm{C}$ for $30 \mathrm{~s}$, extension at $72^{\circ} \mathrm{C}$ for $45 \mathrm{~s}$, and a final extension of $10 \mathrm{~min}$. The amplicons were visualized on $1.5 \%$ agarose gel stained with ethidium bromide and photographed and documented. The analysis of the profiles of amplification was performed visually by two observers and transformed into binary data in a matrix, according to the presence (1) or absence (0) of bands. To assess the genetic relationship among the isolates, the matrix was subjected to multivariate analysis (cluster analysis) by the complete linkage method for the calculation of the Euclidean distance and generation of a dendrogram in the Minitab v.16 statistical program.

\section{RESULTS AND DISCUSSION}

In this study, 10 isolated bacteria from the soil on the starch agar Tryptone medium were initially identified as Bacillus spp by standard microbiological methods (Figure 1A). The confirmation of bacterial specimen was performed by PCR with the universal bacterial $16 \mathrm{~S}$ $r D N A$ pair of primers. All isolates $(\mathrm{N}=10)$ amplified a fragment of $370 \mathrm{bp}$ corresponding to bacterial species (Figure 1B).

This marker has been described in the literature as a sequence signature for isolates of bacteria (Greisen et al., 1994). Furthermore, the presumptive morphologic and staining analysis of isolates observed in the optical microscope revealed the case of Gram-positive (Figure 1A). These facts confirm that microorganisms isolated correspond to bacterial specimens.

The procedure of counting considered viable the dilution where it was possible to see from 25 to 250 colonies, i.e., confluent growth was considered as greater than or equal to 300 colony-forming units (CFU). The soil sample presented an average score of $1 \times 10^{5} \mathrm{CFU} / \mathrm{g}$ soil. The macroscopic evaluation of the colonies showed homogeneity in the aspects of color and brightness/opacity (Figure 2A and Table 1).

According to the literature, a microorganism is considered as a good producer of extracellular enzymes in the solid medium when the result of the EI $\geq 2.0$ (Oliveira et al., 2007). In this study, the capacity of production of amylase was verified through the formation of a halo around the colonies after the dish be stained with iodine solution. Although several

Genetics and Molecular Research 16 (3): gmr16039771 

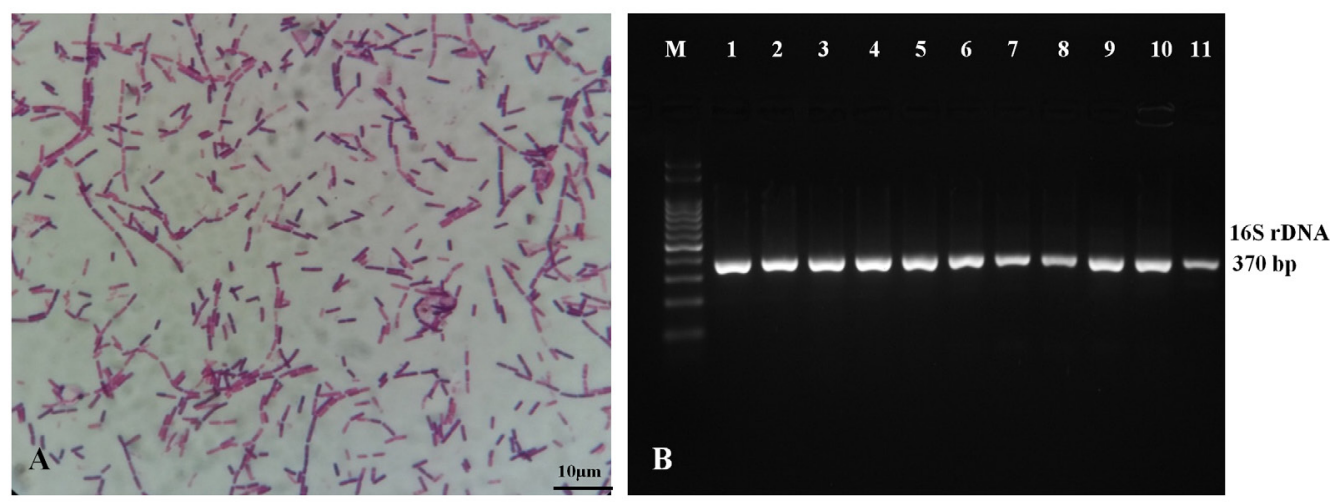

Figure 1. Microscopy and PCR analyses to confirm the genus Bacillus from isolated strains from the soil. A. Isolated bacteria subjected to the standard procedure of Gram staining and visualized in the Nikon Eclipse E200 optical microscope at 1000X magnification. B. PCR analysis with the universal bacterial 16S rRNA gene primers. Lane M: a 100-bp DNA ladder (Ludwig). Lanes 1-10: strains 1 to 10 of Bacillus spp isolated from the soil. Lane 11: positive control (Klebsiella pneumoniae strain). The expected 370-bp amplicon corresponding to $16 S \mathrm{rDNA}$ is indicated on the right side of the gel.
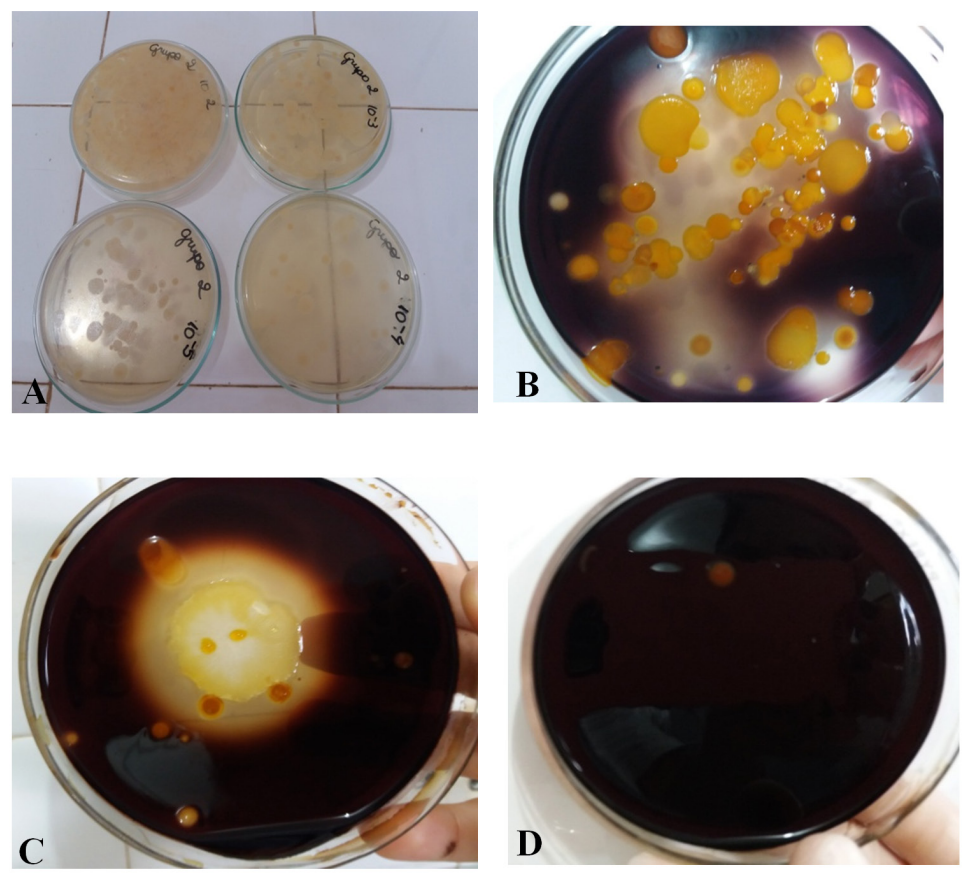

Figure 2. Macroscopic evaluation of the isolated colonies from the soil sample. A. Macroscopic aspects of the colonies obtained from serial and consecutive dilutions from 4 Petri dishes. B. C. D. Macroscopic colonies from 3 Petri dishes after the addition of iodine compound. The halo noticed around the colonies on the Petri dishes in panels B to D indicates the presence of amylase enzyme, which is responsible to the degraded starch contained on the culture media. Panel B shows one phenotypically non-amylase producer colony without the halo forming the starch degradation.

Genetics and Molecular Research 16 (3): gmr16039771 
A.R.E.O. Xavier et al.

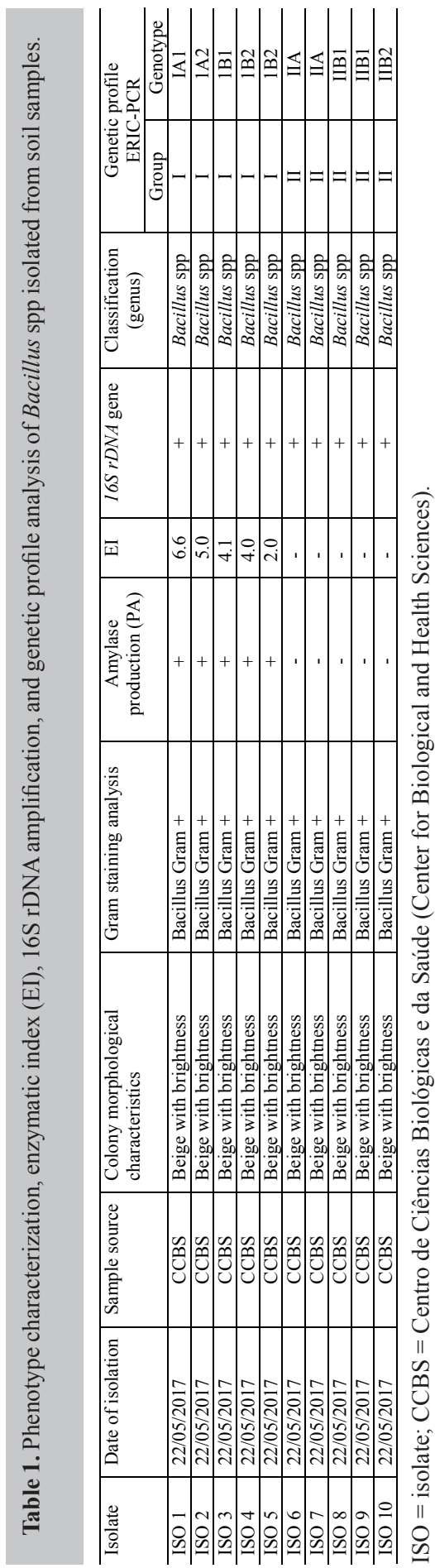

Genetics and Molecular Research 16 (3): gmr16039771 
colonies have presented different halo of growth in the dilutions from $10^{-3}$ to $10^{-5}, 5$ colonies with $\mathrm{EI} \geq 2$, including that one with highest EI (6.6) and 5 non-producers of amylase were selected for this study (Figure 2B, C, D and Table 1). The colonies 2, 3, 4, and 5 exhibited, respectively, 5.0, 4.1, 4.0, and 2.0 as the value of EI (Table 1).

Oliveira et al. (2007) selected strains of rhizobia producer of amylase using flour of peach-palm as substrate. However, the EI of their isolates ranged from 3.1 to 2.1. All isolate producers of amylase selected in this study $(\mathrm{N}=5)$ were good producers of this enzyme in a solid culture medium supplemented with starch. These results showed that the culture medium and conditions of $\mathrm{pH}$ and temperature favored the bioprospection of amylase producer microorganisms by the methodology herein used.

Physical parameters including temperature and $\mathrm{pH}$ play an important role in the secretion of enzymes and induce morphological cell changes. Many of the Bacillus strains used commercially for the production of $\alpha$-amylases have an optimum $\mathrm{pH}$ from 6 to 8 for the enzymatic production (Fooladi and Sajjadian, 2010; Wang et al., 2016). The influence of temperature on the production of amylase by bacteria is reported in the literature (Fooladi and Sajjadian, 2010; Dash et al., 2015; Wang et al., 2016; Gopinath et al., 2017). Konsoula and Liakopoulou-Kryiakides (2004) obtained the maximum production of amylase by thermophilic strains of Bacillus subtilis maintained at $40^{\circ} \mathrm{C}$. Considering the facts mentioned above, we believe that is possibly a better bioprospection of Bacillus sp candidates for amylase producers by increasing the incubation temperature from $37^{\circ}$ to $40^{\circ} \mathrm{C}$. In this study, large colonies were also observed with the aspect of fungi (Figure 2C) with EI around 3.0, which is similar to the isolated bacteria. Fungi are also described in the literature as producers of extracellular enzymes, among which the amylases (Fernandes, 2009; Gopinath et al., 2017).

Aiming at verifying the genetic diversity among isolate producers and non-producers of amylase, the 10 isolates carrying the $16 \mathrm{~S}$ rDNA gene were subjected to analysis of polymorphism by the ERIC-PCR technique. As a result, 13 distinct bands were produced corresponding to the repetitions of this sequence in the genome of isolated microorganisms (Figure 3A).

For band-sharing analysis, the bands in a range from 250 to $2080 \mathrm{bp}$ were considered. The binary matrix made by visual observation of the presence or absence of these bands after subjecting to the cluster analysis by calculation of Euclidean distance generated a dendrogram showing genetic diversity among the isolates. The 10 isolates of Bacillus spp were grouped into two different groups of which 50\% (5/10) profile of group I and 50\% (5/10) of group II. Interestingly, those genotyped as a group I were phenotypically producers of amylase, as well as group II gathered amylase non-producer microorganisms. Although the gene of amylase has not been tracked genetically, the halo formation and the corresponding calculation of the EI confirmed the production of this enzyme in such isolates. Bacillus spp are strong candidate's producers of amylase as reported in the literature (Gopinath et al., 2017)

However, according to the calculation of Euclidean distance, it was possible to determine 7 different genotypes (A1, IA2, IB1, IB2, IIA, IIB1, and IIB2), revealing a different profile. However, there was distinction and homogeneity among the genotypes of strains that produce and that not produce amylase (Figure 3A and Table 1).

Considering the similarity threshold of $85 \%$ as identical strains, 4 isolates were considered clones. Among which the group I isolates 4 and 5 (IB2) with EI, respectively, of 4.0 and 2.0 and the isolates 6 and 7 (IIA) and 8 and 9 (B1) in group II amylase nonproducers. Even though considered identical strains, the values of EI of isolates 4 and 5 were 
not the same; however, the literature describes that same strains genetically identical may have different rates of amylase production (Fernandes, 2009; Gopinath et al., 2017).
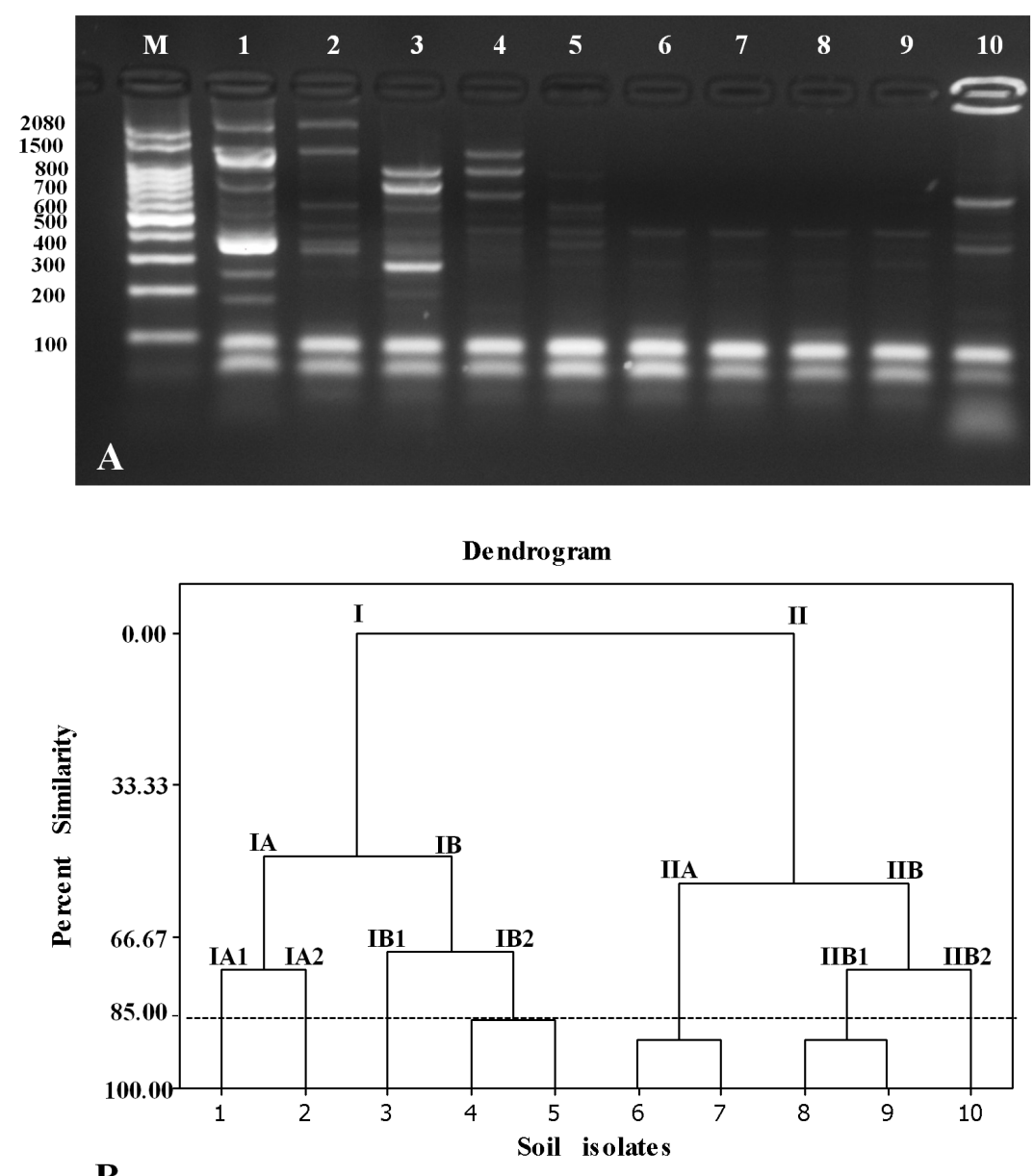

B

Figure 3. Determination of genetic diversity among Bacillus spp isolated from soil samples. A. ERIC-PCR fingerprint of Bacillus spp isolated from the soil presenting the $16 S$ rDNA gene. Lane M: a 100-bp DNA ladder (Ludwig) with size markers indicated at the left side. Lanes 1 to 10: strains 1 to 10 of Bacillus spp isolated from the soil. B. Dendrogram of genetic relationship among the positive Bacillus spp isolated from the soil to $16 \mathrm{~S} \mathrm{rDNA}$ gene amplification by ERIC-PCR. The isolates 1 to 10 were divided into 2 groups (I and II) and subgroups in accordance to the similarity grade as shown on the left side of the figure.

In this study, it was possible to verify an association between phenotype and genotype, since amylase-producing strains showed similarity index higher among themselves than with those not producing this enzyme (Figure 3B). Therefore, it was possible to consider the analysis of polymorphism by ERIC-PCR, a good tool capable of discriminating these two distinct groups. The analysis and genetic diversity by methods based on repetitions (REPPCR, BOX-PCR, and ERIC-PCR) have been considered a good discriminatory tool among the isolates of Bacillus (Shangkuan et al., 2000; da Silva and Valicence, 2013; Kumar et al., 
2014; García et al., 2015). So, a perspective is opened on the use of a microbiological method associated with a molecular method based on repetitive elements (ERIC-PCR) that could be applied to the bacterium bioprospection of the genus Bacillus amylase producers.

\section{Conflicts of interest}

The authors declare no conflict of interest.

\section{ACKNOWLEDGMENTS}

Research supported by the Foundation of Minas Gerais State (FAPEMIG) and the Graduate Program in Biotechnology from the State University of Montes Claros.

\section{REFERENCES}

Akkaya B, Yenidunya AF and Akkaya R (2012). Production and immobilization of a novel thermoalkalophilic extracellular amylase from bacilli isolate. Int. J. Biol. Macromol. 50: 991-995. https://doi.org/10.1016/j.ijbiomac.2012.02.011

Al-Johani NB, Al-Seeni MN and Ahmed YM (2016). Optimization of alkaline $\alpha$-amylase production by thermophilic Bacillus subtilis. Afr. J. Tradit. Complement. Altern. Med. 14: 288-301. https://doi.org/10.21010/ajtcam.v14i1.31

Bhange K, Chaturvedi V and Bhatt R (2016). Simultaneous production of detergent stable keratinolytic protease, amylase and biosurfactant by Bacillus subtilis PF1 using agro industrial waste. Biotechnol. Rep. (Amst.) 10: 94-104. https:// doi.org/10.1016/j.btre.2016.03.007

da Silva RB and Valicente FH (2013). Molecular characterization of Bacillus thuringiensis using rep-PCR. Springerplus 2: 641. https://doi.org/10.1186/2193-1801-2-641

Dash BK, Rahman MM and Sarker PK (2015). Molecular identification of a newly isolated Bacillus subtilis BI19 and optimization of production conditions for enhanced production of extracellular amylase. BioMed Res. Int. 2015: 859805. https://doi.org/10.1155/2015/859805

Duan H, Chai T, Liu J, Zhang X, et al. (2009). Source identification of airborne Escherichia coli of swine house surroundings using ERIC-PCR and REP-PCR. Environ. Res. 109: 511-517. https://doi.org/10.1016/j.envres.2009.02.014

Fernandes AP (2009). Avaliação do potencial enzimático de fungos filamentosos isolados de diferentes fontes. Dissertação (Mestrado em Ciência dos Alimentos). Universidade Federal de Lavras, Lavras.

Fooladi J and Sajjadian A (2010). Screening the thermophilic and hyperthermophilic bacterial population of three Iranian hot-springs to detect the thermostable $\alpha$-amylase producing strain. Iran. J. Microbiol. 2: 46-50.

García K, Ibarra JE, Bravo A, Díaz J, et al. (2015). Variability of Bacillus thuringiensis strains by ERIC-PCR and biofilm formation. Curr. Microbiol. 70: 10-18. https://doi.org/10.1007/s00284-014-0675-8

Ghazala I, Haddar A, Romdhane MB and Ellouz-Chaanouni S (2016). Screening and Molecular Identification of New Microbial Strains for Production of Enzymes of Biotechnological Interest. Braz. Arch. Biol. Technol. 59: e16150152. https://doi.org/10.1590/1678-4324-2016150152

Gopinath SC, Anbu P, Arshad MK, Lakshmipriya T, et al. (2017). Biotechnological Processes in Microbial Amylase Production. BioMed Res. Int. 2017: 1272193. https://doi.org/10.1155/2017/1272193

Greisen K, Loeffelholz M, Purohit A and Leong D (1994). PCR primers and probes for the 16S rRNA gene of most species of pathogenic bacteria, including bacteria found in cerebrospinal fluid. J. Clin. Microbiol. 32: 335-351

Hankin R and Anagnostakis SL (1975). The use of solid media for detection of enzymes production by fungi. Mycologia 67: 597-607. https://doi.org/10.2307/3758395

Kiran T, Asad W, Siddiqui S, Ajaz M, et al. (2015). Industrially important hydrolytic enzyme diversity explored in stove ash bacterial isolates. Pak. J. Pharm. Sci. 28: 2035-2040.

Konsoula Z and Liakopoulou-Kyriakides M (2004). Hydrolysis of starches by the action of an [alpha]-amylase from Bacillus subtilis. Process Biochem. 39:1745-1749.

Kumar A, Kumar A and Pratush A (2014). Molecular diversity and functional variability of environmental isolates of Bacillus species. Springerplus 3: 312. https://doi.org/10.1186/2193-1801-3-312

Liu RF, Huang CL and Feng H (2015). Salt stress represses production of extracellular proteases in Bacillus pumilus. Genet. Mol. Res. 14: 4939-4948. https://doi.org/10.4238/2015.May.11.27

Genetics and Molecular Research 16 (3): gmr16039771 
Ma Y, Shen W, Chen X, Liu L, et al. (2016). Significantly enhancing recombinant alkaline amylase production in Bacillus subtilis by integration of a novel mutagenesis-screening strategy with systems-level fermentation optimization. $J$. Biol. Eng. 10: 13. https://doi.org/10.1186/s13036-016-0035-2

Oliveira AN, Oliveira LA, Andrade JS and Chagas-Júnior AF (2007). Produção de amilase por rizóbios, usando farinha de pupunha como substrato. Food Sci. Technol. (Campinas) 27: 61-66. https://doi.org/10.1590/S010120612007000100011

Pandey A, Nigam P, Soccol CR, Soccol VT, et al. (2000). Advances in microbial amylases. Biotechnol. Appl. Biochem. 31: 135-152. https://doi.org/10.1042/BA19990073

Sahnoun M, Kriaa M, Elgharbi F, Ayadi DZ, et al. (2015). Aspergillus oryzae S2 alpha-amylase production under solid state fermentation: optimization of culture conditions. Int. J. Biol. Macromol. 75: 73-80. https://doi.org/10.1016/j. ijbiomac.2015.01.026

Sánchez Blanco A, Palacios Durive O, Batista Pérez S, Díaz Montes Z, et al. (2016). Simultaneous production of amylases and proteases by Bacillus subtilis in brewery wastes. Braz. J. Microbiol. 47: 665-674. https://doi.org/10.1016/j. bjm.2016.04.019

Schallmey M, Singh A and Ward OP (2004). Developments in the use of Bacillus species for industrial production. Can. J. Microbiol. 50: 1-17. https://doi.org/10.1139/w03-076

Shangkuan YH, Yang JF, Lin HC and Shaio MF (2000). Comparison of PCR-RFLP, ribotyping and ERIC-PCR for typing Bacillus anthracis and Bacillus cereus strains. J. Appl. Microbiol. 89: 452-462. https://doi.org/10.1046/j.13652672.2000.01134.x

Wang S, Jeyaseelan J, Liu Y and Qin W (2016). Characterization and Optimization of Amylase Production in WangLB, a High Amylase-Producing Strain of Bacillus. Appl. Biochem. Biotechnol. 180: 136-151. https://doi.org/10.1007/ $\underline{\text { s12010-016-2089-5 }}$

Wang X, Zhao H, Liu G, Cheng X, et al. (2015). Improving production of extracellular proteases by random mutagenesis and biochemical characterization of a serine protease in Bacillus subtilis S1-4. Genet. Mol. Res. 15: gmr.15027831.

Genetics and Molecular Research 16 (3): gmr16039771 